IZA DP No. 10064

Returns to Schooling among Immigrants in Spain: A Quantile Regression Approach

Santiago Budría

Pablo Swedberg

Marlene Fonseca

July 2016 


\title{
Returns to Schooling among Immigrants in Spain: A Quantile Regression Approach
}

\author{
Santiago Budría \\ Universidad Pontificia Comillas, CEEApIA and IZA \\ Pablo Swedberg \\ St. Louis University \\ Marlene Fonseca \\ Universidad de Educación a Distancia
}
Discussion Paper No. 10064
July 2016

IZA

P.O. Box 7240

53072 Bonn

Germany

\author{
Phone: +49-228-3894-0 \\ Fax: +49-228-3894-180 \\ E-mail: iza@iza.org
}

\begin{abstract}
Any opinions expressed here are those of the author(s) and not those of IZA. Research published in this series may include views on policy, but the institute itself takes no institutional policy positions. The IZA research network is committed to the IZA Guiding Principles of Research Integrity.

The Institute for the Study of Labor (IZA) in Bonn is a local and virtual international research center and a place of communication between science, politics and business. IZA is an independent nonprofit organization supported by Deutsche Post Foundation. The center is associated with the University of Bonn and offers a stimulating research environment through its international network, workshops and conferences, data service, project support, research visits and doctoral program. IZA engages in (i) original and internationally competitive research in all fields of labor economics, (ii) development of policy concepts, and (iii) dissemination of research results and concepts to the interested public.
\end{abstract}

IZA Discussion Papers often represent preliminary work and are circulated to encourage discussion. Citation of such a paper should account for its provisional character. A revised version may be available directly from the author. 


\section{ABSTRACT}

\section{Returns to Schooling among Immigrants in Spain: A Quantile Regression Approach*}

This paper explores the impact of educational attainment on immigrant earnings in Spain using a Quantile Regression approach. Most of the previous research on the impact schooling on earnings has focused on the mean effect neglecting the discrepancies that arise from unobserved heterogeneity. This paper uses the Spanish National Immigrant Survey (NIS), a large-scale immigration survey published by the Spanish National Statistics Institute in 2008 . We find that the return to higher education is on average roughly $17 \%$. Interestingly, the impact is twice as strong (20.7\%) for immigrants at the top two quintile(s) of the conditional earnings distribution than for those at the bottom of the distribution (10\%). This result suggests that the benefits derived from higher education are particularly relevant for individuals with stronger unobserved abilities and marketable skills. By contrast, individuals in the middle and particularly lower quintiles fail to reap a significant return. The large degree of heterogeneity for the returns to schooling found in our research suggests that higher education may be less effective among specific population groups.

JEL Classification: $\quad$ C29, D31, 121

Keywords: returns to education, quantile regression, wage inequality

Corresponding author:

Pablo Swedberg

Department of Business and Economics

St. Louis University

Avenida del Valle 34

28003 Madrid

Spain

E-mail: swedberg@slu.edu

\footnotetext{
* Santiago Budría acknowledges the financial support provided by the Spanish Ministry of Education through grants ECO2012-33993 and ECO2012-36480, and by the Fundación Ramón Areces (Research Project: Determinants of social exclusion and recommendations for combating it).
} 


\section{Introduction}

Human capital is a key determinant of individual earnings in the labour market. As a consequence, the analysis of the immigrants' labour market performance has focused on the accumulation of human capital including education. On this matter, previous research (Chiswick, 1978, Chiswick and Miller 2007, Friedberg, 2000) has shown that the main source of the native-immigrant gap is the limited transferability of schooling from the source to the destination country. Our aim is to show that the returns to education may differ greatly between high and low-skilled immigrants and that as a result there are different degrees of transferability of human capital.

The motivation of the analysis is threefold. First, a limitation of the literature to date is that the return to schooling has been calculated in an "average" sense, i.e., assuming that the impact is evenly distributed across the earnings distribution. This interpretation is likely to be unrealistic due to unobserved heterogeneity arising from non-measured abilities and skills that determine a worker's earnings capacity and, arguably, her return to investments in human capital. In this paper we estimate whether returns to schooling differ across quantiles of the conditional earnings distribution.

Secondly, there is some debate in the policy arena on whether educational attainment is associated with unobserved ability. Non-educated immigrants may be, in some ways, less capable and therefore lack essential abilities and skills that are required to perform a highpaying job. If this were the case, their lower wages are a mere statistical illusion that reflects an omitted variables problem rather than a causal relationship between language ability and earnings. In the quantile regression framework, the estimates at different quantiles represent the effect of a given covariate for individuals that have the same observable characteristics but, due to unobserved earnings capacity, are located at different points of the earnings distribution. By 'unobserved earnings capacity' we are referring to all the unmeasured characteristics that actually affect the worker's position in the wage distribution, including not only individual-level capacities, but also contextual-level characteristics such as ethnicity and workplace conditions. Thus, we show how immigrant workers who acquired schooling within the various segments of the earnings distribution are affected relative to their non-educated counterparts. The major advantage of this approach is that it prevents us from comparing proficient individuals enjoying an advantageous earnings capacity with non-educated individuals subject to an unfavourable earnings condition, thus eliminating the potential bias arising from unobserved heterogeneity. This perspective has proven fruitful to ascertain whether educational and skills mismatches entail a productivity loss (McGuiness \& Bennet, 2007, Bárcena et al., 2012).

Thirdly, our approach has distributional implications. Average estimates assume that the marginal impact of schooling on earnings is constant over the earnings distribution. In this case, 
the impact can be represented by a shift (to the right) of the conditional wage distribution. By contrast, quantile returns measure the wage effects of education at different points of the distribution. As a result changes are not only shown locally but also in the shape of the distribution. In other words, differences in quantile returns represent the wage differential between individuals that are equally educated but located at different quantiles.

Therefore we shed new light on the interplay between schooling and earnings among immigrants in Spain. This is done by providing Quantile Regression (QR) estimates for the effect that education exerts at different segments of the conditional earnings distribution. The paper uses the Spanish National Immigrant Survey (NIS), a large-scale immigration survey published in 2008 by the Spanish National Statistics Institute.

The analysis of QR estimate is also useful to ascertain the extent of earnings dispersion within education groups. This notion is based on a simple idea: education, rather than assuring a certain amount of earnings, gives access to a distribution of earnings. We characterize that distribution by using Ordinary Least Squares (OLS) and Quantile Regression (QR). OLS estimates can be interpreted as the average effect that education has on the sample population's wages. In this case, the effect of having one additional level of education can be represented by a shift (to the right) of the conditional wage distribution. With QR, in turn, we measure the wage effects of education at different points of the distribution, thus describing changes not only at the specific location but also at the shape of the distribution. This issue has important policy implications, as it suggests that the impact of an educational expansion on overall wage inequality may largely depend on the underlying educational distribution. We explicitly differentiate between three education levels: primary or less, secondary and tertiary education.

Such heterogeneous effects may have pronounced implications for the design of effective integration policies. A common policy priority in OECD countries is labour market integration and the strengthening of educational aspects (OECD, 2012). In line with this view, the Spanish Strategic Plan for Citizenship and Integration 2011-2014 acknowledged the fact that immigration poses specific challenges that must be tackled and includes education amongst its priorities, the plan "considers education as a vital element for the construction of a more cohesive society" (Ministry of Labour and Immigration, 2011). Unfortunately, the scope attributed to such policies may be more modest than presumed if workers at the lower segments of the earnings distribution fail to reap relevant returns from schooling. This paper sheds further light on this issue by assessing the interaction between earnings and educational attainment among immigrants in the Spanish labour market.

The rest of the paper is organized as follows. In Section 1 we review the literature. In Section 2 we present the dataset and variables. In Section 3 we present the quantile regression model. The results are presented in Section 4. Section 5 discusses the main findings and their theoretical implications. Section 6 contains the concluding remarks. 


\section{Background and review of the literature}

Immigration and the Spanish labour market are extremely relevant topics given the rapid transformation experienced by the population in Spain during the period 1999-2009. According to OECD estimates (2013) the stock of foreign-born population increased from $4.9 \%$ of the total population in 2000 to $14.6 \%$ in 2011 , representing roughly 6.738 .000 immigrants. Accordingly Spain ranks fifth among OECD countries in stocks of foreign-born population. Conversely, the economic downturn initiated in the third quarter of 2008 has slowed down migration inflows, increased migration outflows and more than doubled the unemployment rate. As a result of the decline in new entries (OECD, 2013) and the increase in return migration due to worsening labour market conditions, Spain has experienced continuous negative net migration since 2010. In 2013 in particular, 291.041 immigrants arrived in Spain and 547.890 individuals left the country according to the Spanish National Statistics Institute (INE). Strikingly Spanish-speaking Colombians, Ecuadorians, Bolivians and Peruvians accounted for almost half of the leavers. Indeed language may play a crucial role in return migration since five of the ten largest immigrant populations that arrived in Spain are from Spanish-speaking countries. Given that Spain is the only Spanish-speaking country in the EU and Spaniards typically exhibit very poor foreign language skills as shown by the Eurobarometer 2012, many young Spaniards compete for jobs against immigrants.

The economic recession has continued in Spain since late 2011 and the latest and most adverse consequence of the double-dip recession is the second highest unemployment rate in the European Union-23\% (Eurostat, 2015). According to new figures released by Eurostat, foreigners in Spain experience the highest unemployment rate-37\% among non-nationals living in EU countries.

Moreover, education is a crucial policy instrument to reduce income inequality. A more balanced distribution of schooling will result most likely in a more even distribution of income. Evidence in Europe (Machado and Mata, 2001, 2005, Hartog et al., 2001) and the U.S. (Buchinsky, 1994, Autor et al., 2008) show that the returns to education tend to increase as we move up the earnings distribution. In addition, the returns to education are lower among foreign-born workers in all immigrant-receiving countries. In his pioneering research Chiswick (1978) found that the return to education on earnings is $1.5 \%$ lower for immigrant in the U.S. International evidence shows that immigrants experience a negative wage gap with respect to native earnings. These findings have been reported for Israel (Chiswick, 1979) and Germany (Dustmann, 1993) among others. Moreover, the wage gap is inversely related to years since migration, even though the degree of earnings assimilation is found to differ across studies $(\mathrm{Hu}$, 2000, Friedberg, 2000, Adsera \& Chiswick, 2007, Benstock et al. 2010). Some findings suggest 
that the source country's level of economic development has a positive impact on the transferability of human capital (Bratsberg and Ragan, 2002).

Additional efforts have been conducted to test whether there are asymmetric effects in the immigrant-native wage gap across the wage distribution. In particular, Chiswick, Le and Miller (2008) measure the immigrant-native gap in the US and Australia focusing on the partial impact of schooling and work experience at each decile of the earnings distribution. Their results show that immigrants from non-English speaking countries experience lower returns to human capital skills at each decile of the earnings distribution than do immigrants from English speaking countries. In particular the wage penalty for non-English- speaking immigrants increases beyond the third decile of the wage distribution. Similarly, Billger and Lamarche (2010) examine native-immigrant earnings differentials throughout the wage distribution in the US and the UK and find that immigrants from non-English speaking countries receive substantially lower wages throughout the wage distribution. In this case, the wage penalty is stronger for male immigrants at the bottom of the wage distribution. This may highlight that these immigrants select into low-paying jobs and/or the presence of wage discrimination in the UK. Conversely, the wage penalty is greater for non-English speaking female workers at the top of the earnings distribution in the US. Using data from Spain, Anton et al. (2010) find that the immigrant-native wage gap increases up to $25 \%$ when we move up along the earnings distribution. This result suggests that there may be a glass ceiling for immigrant workers in Spain. Lastly for Spain, Sanromá et al. (2008) examine the returns to human capital acquired in the host and home country and show that the impact of schooling acquired in the host country is stronger, showing that the limited degree of transferability of schooling. Unfortunately, Their results are not show throughout the income distribution.

All in all, these results show that migrants cannot fully utilize their human capital attributes, and that immigrants with high and low unobserved earnings capacity are affected. To our knowledge, our paper is the first attempt to capture the impact of educational attainment on immigrant earnings at different points of the wage distribution in Spain.

\section{Data and definition of variables}

The data is taken from the Spanish National Immigrant Survey (Encuesta Nacional de Inmigrantes), a large-scale immigration survey carried out by the Spanish National Statistics Institute. The data collection was conducted between November 2006 and February 2007 and was based on the Municipal Census (Padrón Municipal). The original survey sample comprises approximately 15,500 individuals. The NIS provides detailed information on the sociodemographic characteristics of immigrants and their previous and current employment status. 
Immigrants are defined as any individual born abroad (regardless of their nationality) who at the time of being interviewed had reached at least 16 years of age and had resided in Spain for at least a year or longer, or had the intention to remain in Spain for at least a year.

The estimating sample consists of private sector men who are between 18 and 65 years old and work regularly between 15 and 70 hours a week. Self-employed individuals, as well as those whose main activity status is paid apprenticeship, training, and unpaid family workers have been excluded from the sample. Women are disregarded on account of the extra complications derived from potential selectivity bias. Dropping observations, including item non-response, leaves us with a final sample of 2,849 individuals.

Table 1 provides summary statistics by educational attainment. Roughly $22.3 \%$ of the individuals included in the sample obtained tertiary education, whereas $59.3 \%$ have secondary education and $18.3 \%$ only acquired primary schooling. Nearly $71 \%$ of the total sample reports Spanish language proficiency, whereas the remaining $29 \%$ has a weak knowledge of the destination language.

Furthermore, individuals included in the sample are 36.8 years old on average, while the average age of arrival is 24.5 years. This suggests that immigrant men have been in Spain for 11.7 years on average. Work experience amounts to about 11.7 years, while $48.9 \%$ of the migrants included in the sample enjoy a permanent contract. The majority are married $(57.7 \%)$ and have children living at home (62.7\%). Almost a third of the sample (32.6\%) reports previous unemployment experience, while almost another third declares not holding legal documents for residency in Spain (31.1\%). Immigrants are mainly from Latin America (39.8\%), Central and Western Europe (21.3\%), and are more likely to work in the Administration $(30.0 \%)$ and the Agriculture \& Fishery (23.3\%) sectors.

\section{The model}

The quantile regression model can be written as

$$
\text { ln } w_{i}=X_{i} \beta_{\theta}+e_{\theta i} \quad \text { with } \text { Quant }_{\theta}\left(\ln w_{i} \mid X_{i}\right)=X_{i} \beta_{\theta}
$$

where $X_{i}$ is the vector of exogenous variables and $\beta_{\theta}$ is the vector of parameters. Quant $_{\theta}\left(\ln w_{i} \mid X_{i}\right)$ denotes the $\theta$ th conditional quantile of $\ln w$ given $X$. The $\theta$ th regression quantile, $0<\theta<1$, is defined as a solution to the problem

$$
\operatorname{Min}_{\beta \in R^{k}}\left\{\sum_{i: \ln w_{i} \geq x_{i} \beta_{\theta}} \theta\left|\ln w_{i}-X_{i} \beta_{\theta}\right|+\sum_{i: \ln w_{i}<x_{i} \beta_{\theta}}(1-\theta)\left|\ln w_{i}-X_{i} \beta_{\theta}\right|\right\}
$$


which, after defining the check function $\rho_{\theta}(z)=\theta z$ if $z \geq 0$ or $\rho_{\theta}(z)=(\theta-1) z$ if $z<0$, can be written as

$$
\underset{\beta \in R^{k}}{\operatorname{Min}}\left\{\sum_{i} \rho_{\theta}\left(\ln w_{i}-X_{i} \beta_{\theta}\right)\right\}
$$

This problem is solved using linear programming methods. Standard errors for the vector of coefficients are obtainable by using the bootstrap method described in Buchinsky (1998).

By combining OLS with quantile regression, we can assess the impact of schooling on wage inequality between and within groups. While OLS returns measure the average wage differential between groups with different levels of schooling (conditional on observable characteristics), differences in quantile returns represent the wage differential induced by education between individuals that are in the same group but located at different quantiles along the wage distribution. Throughout the paper, and following Buchinsky (1994), we will use the difference in the returns between conditional quantiles as a measure of within-groups inequality.

Our wage equation is

$$
\ln w_{i}=X_{i} \beta+\gamma_{1} \text { Secondary }_{i}+\gamma_{2} \text { Tertiary }_{i}+\varepsilon_{i}
$$

where $w$ is hourly earnings. $X$ includes Spanish language proficiency (yes/no) ${ }^{1}$, potential labour market experience and its square, years since migration, type of contract (temporary or permanent), marital status (single, divorced or widowed, reference: married), children at home, previous unemployment spells of 3 months or longer in Spain (yes/no), legal status (documented or undocumented), occupational dummies (according to the one digit level National Classification of Occupations), the immigrant's origin geographical region (Maghreb, Sub-Saharan Africa, Eastern Europe, North and Latin-America, Asia or Oceania, reference: Central and Western Europe) and dummies for region of residence in Spain. The choice of these variables is duly motivated by the immigration adjustment literature ${ }^{2}$. Finally, the crux of the present analysis will be on Secondary and Tertiary Education. These variables are activated

\footnotetext{
${ }^{1}$ The Spanish proficiency question on the NIS is: "Thinking of what you need for communicating at work, at the bank, with the public authorities/administration. How well do you speak Spanish?" with answers ranging from 1 ('very well') to 4 ('need to improve'). These responses were used to define SP, a dummy variable that takes value one if the immigrant has Spanish proficiency (1-very well), zero otherwise.

${ }^{2}$ Other conventional controls such as tenure and work experience in the home and host country were disregarded due to large non-response items.
} 
only if the highest education level completed by the individual is, respectively, secondary or tertiary education. The reference category is 'less than secondary education'.

\section{Empirical results}

In this section, we calculate OLS returns as well as conditional returns to education at the representative quantiles: $0.10,0.20, . ., 0.90$, which we denote by $10 \mathrm{q}, 20 \mathrm{q} . . .90 \mathrm{q}$ each decile henceforth. Table 2 reports the main results. A glance at the OLS estimates reveals that for schooling only tertiary education has a strong and statistically significant impact on immigrant earnings in the Spanish labour market. The coefficient for secondary education fails to be statistically significant, suggesting that the Spanish labour market does not discriminate between those immigrants with secondary and lower levels of education. On the contrary, tertiary education carries a significant premium, of about $16.8 \%$. Before discussing how these estimates change at the different segments of the earnings distribution, it is convenient to unveil the role of the remaining covariates included.

The results are as follows. Being proficient in Spanish increases wages by 9 percentage points (pp). As expected, work experience is associated with higher earnings, though at a decreasing rate. Having a permanent contract is associated with higher wages at $5.6 \%$, whereas previous unemployment experience decreases wages by about $5.4 \%$. In addition, we find conspicuous earnings differentials among immigrants from different geographical regions. Relative to the reference individual from Central and Western Europe, workers from Maghreb, Sub-Saharan Africa, Eastern Europe, Latin America and Asia reap significantly lower earnings. Finally, the results suggest that immigrants working in Management earn an additional $38.7 \%$ and immigrants in the Technology \& Sciences sector receive $48.6 \%$ higher wages, relative to the reference category 'Unqualified occupations'. Administration, Agriculture \& Fishery and Manufacturing \& Construction carry a lower despite significant premium

\subsection{Are returns to schooling constant across the earnings distribution?}

Next, we turn to the estimates at different quantiles of the wage distribution. First, we check whether the wage dispersion is constant across education groups. We reject this hypothesis. We find that moving from the bottom to the top quantile the return to tertiary education rises from $10.6 \%$ to $20.7 \%$. This 10.1 p.p. differential shows that the estimate provided by OLS masks the return to education at different points of the wage distribution and suggests that tertiary education has a positive impact on within-groups dispersion: if returns are 
higher at the upper segments of the distribution and we provide higher education to immigrants that are seemingly equal but located at different quantiles, then their wages will become more unequal. Figure 1 depicts the quantile-return profile for the secondary and tertiary education along with the OLS average return (horizontal line). It is interesting to note that for most segments of the conditional wage distribution the return to tertiary education is actually below the average OLS return. Only at the top two quantiles does the return to tertiary education exceed the OLS return. All in all, this pattern suggests that returns to education among immigrants in Spain cannot be described in an average sense.

Furthermore, OLS estimates for the return to secondary education fail to be statistically significant. A more detailed look at table 2 suggests that this also applies to most estimates at the intermediate and lower quantiles of the earnings distribution. However, returns to secondary education are positive and statistically significant at $80 \mathrm{q}$ and 90q. Although the estimates are relatively low as compared to the return to tertiary education $(4.7 \%$ and $6.4 \%$, respectively), these findings suggest that relying on OLS estimates may be seriously misleading. Specifically, we find that immigrant workers located at the upper segments of the earnings distribution are able to reap significant returns to secondary education. Figure 1 also illustrates the increasing pattern for the returns to secondary education.

Finally, we note that the differential between the top and the bottom quantile is lower for secondary than for tertiary education. This implies that the extent of conditional inequality for those with a tertiary level education is larger than for immigrants with secondary education. This result warns that the use of years of schooling as a covariate in the wage regression may be inappropriate, as it presumes that the impact of an additional year of schooling on within-groups dispersion is constant across education levels. Instead, the use of education dummies uncovers important differences between academic qualifications. Specifically, our estimates suggest that most of the inequality-increasing effect of schooling is due to tertiary education or, put differently, the impact of education on within-group dispersion is large in regards to tertiary education, but very modest for secondary education

\section{---- Insert Figure 1 about here ---}

Table 3 shows whether differences across quantiles are statistically significant. The first row reports the F-test for the equality of the coefficients at 10q and 50q. The second and third rows proceed likewise with 50q and 90q, and 10q and 90q, respectively. The last row reports a joint test of equality of coefficients at all quantiles. The results show that the difference between the estimates at $10 \mathrm{q}$ and $50 \mathrm{q}$ fails to be statistically significant for tertiary education, and the same applies to the 50q-90q differentials. However, when we consider the two opposite end quantiles (10q and 90q) the test rejects the equality of the coefficients. Most importantly, the 
joint test reported at the last row rejects the hypothesis that the return to tertiary education is constant across the wage distribution. As for secondary education, the results are similar. In conclusion, differences between any of the selected quintiles are individually as well as jointly significant.

\section{Conclusions}

In this paper we have shown that the association between earnings and schooling among immigrants in Spain cannot be regarded as constant across the earnings distribution. Seemingly equal individuals can reap very different returns to schooling depending on their relative position at the wage distribution. Researchers and policy makers should take this heterogeneity into consideration when attempting to ascertain the return to educational attainment for different population groups and on the total earnings distribution. To that end, focusing on averages may be seriously misleading.

The results may have very important implications for policy makers, enabling them to target the immigrant population based on their needs and their return to schooling. Such heterogeneous effects may have pronounced implications for the design of effective integration policies. A common policy priority in OECD countries is labour market integration and the strengthening of educational aspects (OECD, 2012). In line with this view, the Spanish Strategic Plan for Citizenship and Integration 2011-2014 acknowledged the fact that immigration poses specific challenges that must be tackled and includes education amongst its priorities, the plan "considers education as a vital element for the construction of a more cohesive society" (Ministry of Labour and Immigration, 2011). Unfortunately, the scope attributed to such policies may be more modest than presumed if workers in the lower segments of the earnings distribution fail to reap relevant returns from schooling. This paper sheds further light on this issue by assessing the interaction between earnings and educational attainment among immigrants in the Spanish labour market.

As a limitation, the paper does not explore selection issues. Therefore, the schooling estimates can be criticized for being 'ex-post' rather than 'ex-ante' effects. Even though quantile regression allows for a non-trivial interaction between unobservable characteristics and the variable of interest, it would be informative to test whether the results change much when education is instrumented. This would allow us to remove elements that simultaneously determine wages and the probability of acquiring more education. However, our dataset does not include valuable instruments that are highly correlated with schooling and are at the same time uncorrelated with earnings. 


\section{References}

Adsera, A. and Chiswick, B. (2007): 'Are there gender and country of origin differences in immigrant labor market outcomes across European destinations?', Journal of Population Economics, vol. 20(3), pp.495-526.

Anton, J.I., Muñoz de Bustillo, R. and Carrera M. (2010). 'From guests to hosts: immigrantnatives wage differentials in Spain', International Journal of Manpower, 31(6), pp.645-659.

Autor, D., L. Katz and M. Kearney (2008): Trends in U.S. Wage Inequality: Revising the Revisionists, Review of Economics and Statistics, vol. 90, no 2, pp. 300-323.

Bárcena, E.; Budría, S.; Moro-Egido, A. I. 2012. Skill Mismatches and Wages among European University Graduates, Applied Economics Letters 19 (15): 1471-1475.

Beenstock, M., Chiswick, B.R., and Paltiel, A., (2010): 'Testing the Immigrant Assimilation Hypothesis with Longitudinal Data', Review of Economics of the Household, vol. 8(1), pp. 727.

Billger, S. and Lamarche C. (2010). 'Immigrant heterogeneity and the earnings distribution in the United Kingdom and United States: new evidence from a panel data quantile regression analysis', IZA Discussion Paper No. 5260.

Bratsberg, B.; Ragan, J. (2002), "The Impact of Host-Country Schooling on Earnings. A Study of Male Immigrants in the United States", Journal of Human Resources vol. XXXVII, n.1, pp. 63-105.

Buchinsky, M. (1998): Recent advances in quantile regression models: a practical guide-ine for empirical research, Journal of Human Resources vol. 33, pp. 88-126.

Chiswick, B. (1978). 'The Effect of Americanization on the Earnings of Foreign-born Men', Journal of Political Economy, Vol. 86, No. 5, pp. 897-921.

Chiswick, B. (1979) "The Economic Progress of Immigrants: Some Apparently Universal Patterns.' In Contemporary Economic Problems 1979. Ed. W. Fellner. Washington, DC: American Enterprise Institute for Public Policy Research. Pp. 357-399.

Chiswick, B.; Miller, P. (2007), The International Transferability of Immigrants' Human Capital Skills, IZA Discussion paper n. 2670, March 2007, 27 p.

Dustmann, C. 1993 “Earnings Adjustment of Temporary Migrants." Journal of Population Economics 6(2):153-168.

European Comission (2012). ' Europeans and their languages', Eurobarometer Special Survey No.386. Available at: http://ec.europa.eu/public opinion/archives/ebs/ebs 386 en.pdf

Friedberg, R. (2000), “You Can’t Take It with You? Immigrant Assimilation and the Portability of Human Capital", Journal of Labor Economics, vol. 18, n. 2, pp. 221-251. 
Hartog, J., P. Pereira and J.A. Vieira (2001): Changing Returns to Education in Portugal during the 1980s and Early 1990s: OLS and Quantile Regression Estimators, Applied Economics, vol. 33, pp. 1021-2037.

Hu, W-Y.(2000): 'Immigrant earnings assimilation: estimates from longitudinal data. American Economic Review, Papers and Proc. vol. 90 (May): 368-372.

Le, A. and Miller, P. (2012). 'Glass ceiling and double disadvantage effects: women in the U.S. labour market', Applied Economics, 42, pp. 603-613.

Machado, J. and J. Mata (2001): Earning functions in Portugal 1982-1994: evidence from quantile regressions, Empirical Economics, vol. 26, pp. 115-134.

Machado, J. and J. Mata (2005): Counterfactual Decomposition of Changes in Wage Distributions using Quantile Regression, Journal of Applied Econometrics, vol. 20, no 4, pp. 445-465.

McGuinness, S.; Bennett, J. 2007. Overqualification and the Graduate Labour Market: A Quantile Regression Approach, Economics of Education Review 26(5): 521-531.

Ministry of Labour and Social Affairs (Ministerio de Trabajo y Asuntos Sociales) (2007):

'Strategic plan for citizenship and integration', Subdirección General de Información Administración y Publicaciones. Available at: http://extranjeros.empleo.gob.es/es/IntegracionRetorno/Plan_estrategico/pdf/PECIingles.pdf

OECD (2012): 'Migration policy developments, International Migration Outlook 2012, OECD Publishing. Available at: http://dx.doi.org/10.1787/migr_outlook-2012-6-en

OECD (2013). 'Migration policy developments, International Migration Outlook 2013', OECD Publishing. Available at: http://www.oecd.org/els/mig/imo2013.htm

Simón, H., Sanromá, E. and Ramos, R. (2008): 'Labour segregation and immigrant and nativeborn wage distributions in Spain: an analysis using matched employer-employee data', Spanish Economic Review, vol. 10(2), pp.135-168. 


\section{FIGURES}

Figure 1. Quantile-return profiles by education levels

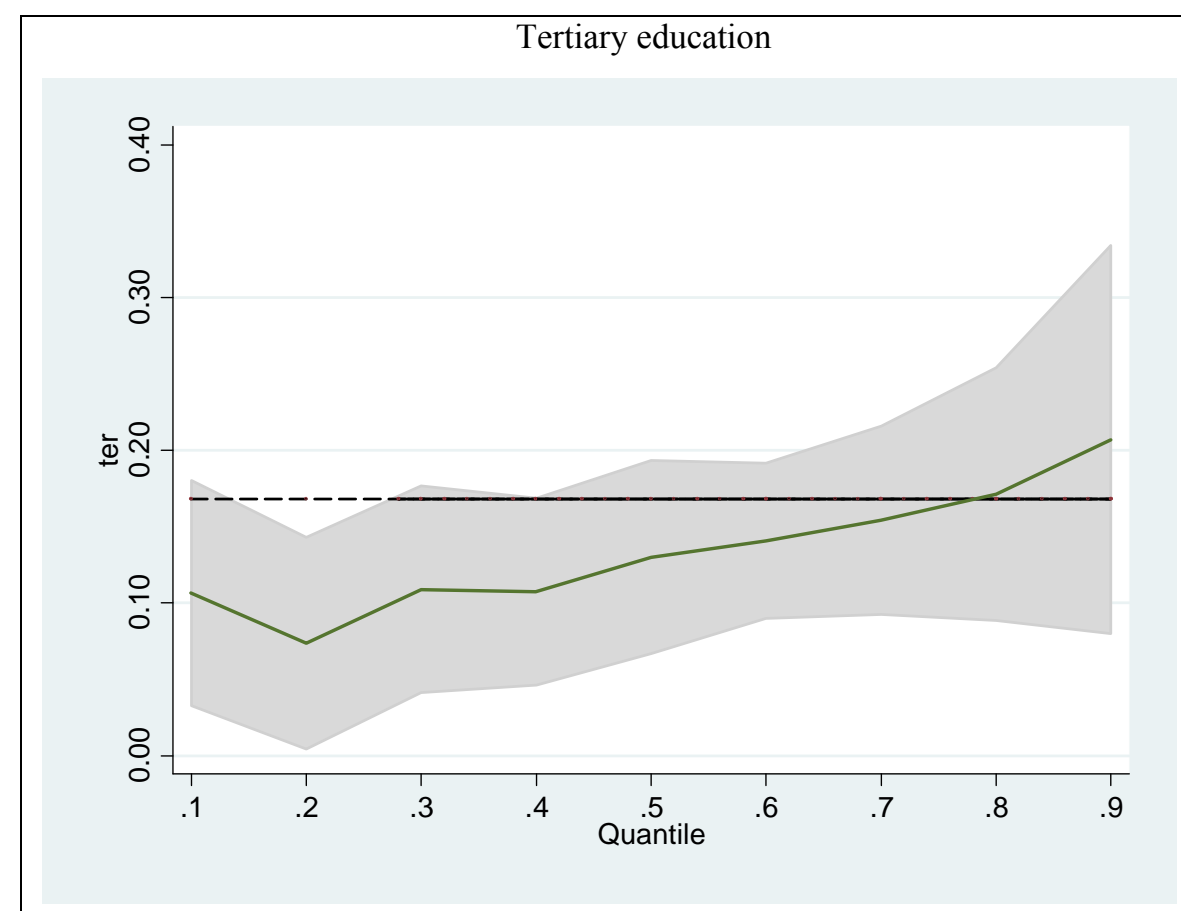

Secondary education

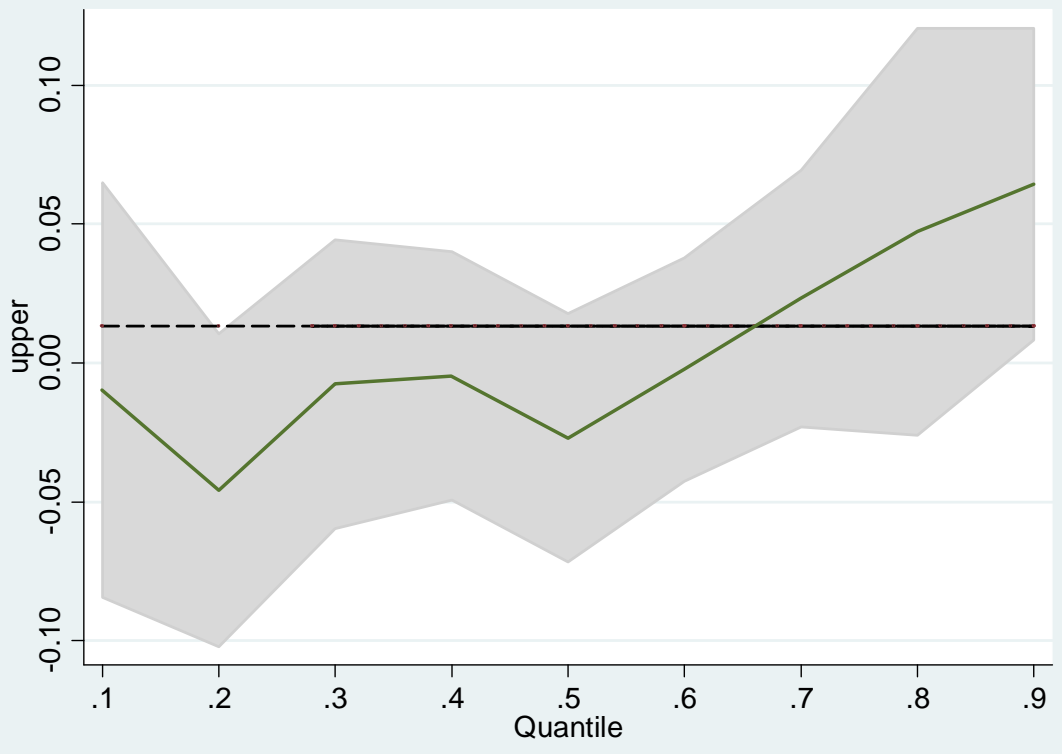




\section{TABLES}

Table 1 . Summary statistics

\begin{tabular}{|c|c|c|c|}
\hline \multirow[t]{2}{*}{ Tertiary education } & 0.223 & Region of origin & \\
\hline & 0.416 & & \\
\hline \multirow[t]{2}{*}{ Secondary education } & 0.593 & Northern Africa & 0.138 \\
\hline & 0.491 & & 0.344 \\
\hline \multirow[t]{2}{*}{ Primary education } & 0.183 & Subsaharan Africa & 0.035 \\
\hline & 0.386 & & 0.184 \\
\hline \multirow[t]{2}{*}{ Proficienct in Spanish } & 0.707 & Eastern Europe & 0.182 \\
\hline & 0.455 & & 0.386 \\
\hline \multirow[t]{2}{*}{ Age } & 36.760 & Western and Central Europe & 0.213 \\
\hline & 8.65 & & 0.409 \\
\hline \multirow[t]{2}{*}{ Age at arrival } & 24.530 & Latin-America & 0.398 \\
\hline & 10.30 & & 0.489 \\
\hline \multirow[t]{2}{*}{ Work experience } & 11.74 & U.S.A., Canada \& Australia & 0.008 \\
\hline & 11.18 & & 0.091 \\
\hline \multirow[t]{2}{*}{ Permanent contract } & 0.489 & & \\
\hline & 0.500 & Occupation sector & \\
\hline \multirow[t]{2}{*}{ Years since migration } & 11.74 & Army & 0.002 \\
\hline & 11.18 & & 0.042 \\
\hline \multirow[t]{2}{*}{ Permanent contract } & 0.489 & Management & 0.040 \\
\hline & 0.500 & & 0.197 \\
\hline \multirow[t]{2}{*}{ Married } & 0.577 & Technology and Sciences & 0.155 \\
\hline & 0.494 & & 0.363 \\
\hline \multirow[t]{2}{*}{ Single } & 0.372 & Services & 0.133 \\
\hline & 0.483 & & 0.340 \\
\hline \multirow[t]{2}{*}{ Divorced } & 0.049 & Administration & 0.300 \\
\hline & 0.216 & & 0.451 \\
\hline \multirow[t]{2}{*}{ With children } & 0.627 & Agriculture and Fishery & 0.233 \\
\hline & 0.483 & & 0.422 \\
\hline \multirow[t]{2}{*}{ Previous unemployment experience } & 0.326 & Manugfacturing, Construction & 0.137 \\
\hline & 0.469 & & 0.344 \\
\hline \multirow[t]{2}{*}{ Ilegal status } & 0.312 & & \\
\hline & 0.463 & & \\
\hline
\end{tabular}

Note to Table 1: a) Source: Spanish National Immigrant Survey; b) Standard deviations are in smaller type. 
Table 2 - OLS and QR estimates

\begin{tabular}{|c|c|c|c|c|c|c|c|c|c|c|}
\hline & \multirow[t]{2}{*}{ OLS } & \multicolumn{9}{|c|}{ QR } \\
\hline & & $10 \mathrm{q}$ & $20 \mathrm{q}$ & $30 \mathrm{q}$ & $40 q$ & $50 \mathrm{q}$ & $60 \mathrm{q}$ & $70 q$ & $80 q$ & $90 q$ \\
\hline \multirow[t]{2}{*}{ Tertiary education } & 0.168 & 0.106 & 0.074 & 0.109 & 0.107 & 0.130 & 0.141 & 0.154 & 0.171 & 0.207 \\
\hline & 6.93 & 1.59 & 1.61 & 2.31 & 2.66 & 6.72 & 4.23 & 4.11 & 3.95 & 11.13 \\
\hline \multirow[t]{2}{*}{ Secondary education } & 0.013 & -0.010 & -0.045 & -0.008 & -0.005 & -0.027 & -0.002 & 0.023 & 0.047 & 0.064 \\
\hline & 0.75 & -0.24 & -4.11 & -0.30 & -0.15 & -2.25 & -0.11 & 1.53 & 3.30 & 3.81 \\
\hline \multirow[t]{2}{*}{ Spanish language proficiency } & 0.090 & 0.079 & 0.110 & 0.101 & 0.103 & 0.120 & 0.117 & 0.103 & 0.086 & 0.050 \\
\hline & 5.04 & 1.67 & 26.38 & 3.84 & 3.69 & 4.82 & 4.51 & 3.97 & 2.41 & 0.96 \\
\hline \multirow[t]{2}{*}{ Experience } & 0.009 & 0.008 & 0.009 & 0.008 & 0.007 & 0.006 & 0.008 & 0.009 & 0.011 & 0.009 \\
\hline & 3.84 & 1.67 & 3.09 & 2.28 & 2.40 & 1.62 & 3.26 & 3.20 & 3.39 & 2.28 \\
\hline \multirow[t]{2}{*}{ Experience $^{2}(\mathrm{x} 1000)$} & -0.119 & -0.159 & -0.189 & -0.159 & -0.125 & -0.082 & -0.132 & -0.138 & -0.147 & -0.057 \\
\hline & -2.64 & -1.69 & -2.96 & -2.12 & -2.01 & -1.23 & -2.71 & -2.67 & -2.55 & -0.72 \\
\hline \multirow[t]{2}{*}{ Years since migration } & -0.001 & -0.002 & -0.001 & -0.001 & 0.000 & 0.000 & 0.000 & 0.000 & -0.001 & -0.002 \\
\hline & -1.26 & -0.93 & -0.89 & -0.82 & -0.39 & 0.27 & 0.40 & -0.45 & -0.46 & -0.83 \\
\hline \multirow[t]{2}{*}{ Permanent contract } & 0.056 & 0.069 & 0.062 & 0.050 & 0.036 & 0.049 & 0.052 & 0.037 & 0.014 & 0.009 \\
\hline & 4.57 & 3.31 & 4.02 & 3.16 & 2.48 & 3.45 & 4.17 & 3.02 & 0.97 & 0.47 \\
\hline \multirow[t]{2}{*}{ Single } & -0.016 & -0.055 & -0.066 & -0.052 & -0.037 & -0.011 & 0.008 & 0.010 & -0.001 & 0.000 \\
\hline & -1.03 & -2.08 & -2.42 & -2.36 & -1.73 & -0.45 & 0.36 & 0.49 & -0.03 & -0.01 \\
\hline \multirow[t]{2}{*}{ Divorced } & -0.054 & 0.016 & 0.035 & 0.027 & -0.022 & -0.043 & -0.065 & -0.075 & -0.068 & -0.063 \\
\hline & -2.25 & 0.37 & 0.87 & 0.92 & -0.81 & -1.77 & -2.69 & -2.93 & -1.96 & -1.16 \\
\hline \multirow[t]{2}{*}{ Children } & 0.016 & -0.015 & -0.009 & 0.005 & 0.010 & 0.021 & 0.018 & 0.014 & -0.002 & 0.018 \\
\hline & 1.05 & -0.48 & -0.33 & 0.20 & 0.48 & 0.95 & 0.98 & 0.69 & -0.11 & 0.82 \\
\hline \multirow[t]{2}{*}{ Previous unemployment experience } & -0.054 & -0.035 & -0.039 & -0.046 & -0.048 & -0.060 & -0.060 & -0.058 & -0.054 & -0.033 \\
\hline & -4.37 & -1.49 & -1.65 & -1.92 & -2.46 & -3.76 & -4.40 & -4.22 & -3.64 & -1.57 \\
\hline \multirow[t]{2}{*}{ Ilegal status } & 0.009 & 0.030 & 0.070 & 0.034 & 0.003 & -0.016 & -0.027 & -0.034 & -0.042 & -0.038 \\
\hline & 0.65 & 1.00 & 3.33 & 1.69 & 0.18 & -1.15 & -2.14 & -2.42 & -2.37 & -1.62 \\
\hline \multicolumn{11}{|l|}{ Region of origin } \\
\hline Maghreb & -0.148 & -0.122 & -0.148 & -0.166 & -0.178 & -0.186 & -0.181 & -0.133 & -0.096 & -0.091 \\
\hline & -6.45 & -3.47 & -4.81 & -5.01 & -6.30 & -6.91 & -5.81 & -5.40 & -3.06 & -1.65 \\
\hline Sub-saharan Africa & -0.144 & -0.175 & -0.166 & -0.159 & -0.137 & -0.142 & -0.137 & -0.114 & -0.104 & -0.097 \\
\hline & -4.41 & -3.26 & -3.42 & -4.05 & -4.19 & -4.10 & -4.16 & -4.10 & -3.16 & -1.27 \\
\hline Eastern Europe & -0.139 & -0.187 & -0.168 & -0.160 & -0.144 & -0.118 & -0.094 & -0.066 & -0.046 & -0.053 \\
\hline & -6.17 & -6.03 & -5.78 & -4.45 & -4.94 & -4.10 & -2.93 & -2.19 & -1.41 & -1.10 \\
\hline Asia & -0.091 & -0.215 & -0.094 & -0.117 & -0.106 & -0.083 & -0.082 & -0.064 & 0.036 & 0.027 \\
\hline & -2.34 & -2.32 & -1.29 & -2.01 & -2.13 & -1.87 & -2.16 & -1.06 & 0.56 & 0.27 \\
\hline Latin-america & -0.183 & -0.181 & -0.209 & -0.212 & -0.196 & -0.213 & -0.209 & -0.166 & -0.119 & -0.099 \\
\hline & -10.03 & -5.98 & -7.08 & -7.06 & -6.97 & -8.06 & -8.67 & -8.97 & -4.57 & -2.45 \\
\hline Australia-North America & -0.051 & 0.055 & 0.031 & -0.074 & -0.068 & -0.126 & -0.146 & -0.069 & 0.055 & 0.056 \\
\hline & -0.79 & 0.45 & 0.44 & -1.00 & -0.76 & -1.28 & -1.27 & -0.51 & 0.45 & 0.56 \\
\hline Occupation sector & & & & & & & & & & \\
\hline Army & 0.247 & 0.154 & 0.238 & 0.141 & 0.214 & 0.089 & 0.240 & 0.179 & 0.099 & 0.606 \\
\hline & 1.79 & 0.73 & 1.12 & 0.69 & 1.08 & 0.43 & 0.94 & 0.54 & 0.30 & 1.74 \\
\hline Management & 0.387 & 0.023 & 0.163 & 0.182 & 0.343 & 0.451 & 0.517 & 0.603 & 0.667 & 0.742 \\
\hline & 11.90 & 0.23 & 2.05 & 2.41 & 3.62 & 6.40 & 6.86 & 9.60 & 8.64 & 7.41 \\
\hline Technology and Sciences & 0.486 & 0.340 & 0.382 & 0.418 & 0.461 & 0.505 & 0.530 & 0.556 & 0.571 & 0.625 \\
\hline & 21.68 & 8.67 & 12.09 & 11.36 & 11.50 & 11.89 & 12.46 & 15.11 & 16.37 & 11.39 \\
\hline Services & 0.131 & -0.055 & -0.023 & -0.021 & -0.010 & -0.033 & -0.032 & -0.019 & -0.011 & 0.028 \\
\hline & 3.96 & -1.33 & -0.81 & -0.78 & -0.43 & -1.69 & -1.60 & -0.79 & -0.43 & 0.68 \\
\hline Administration & -0.015 & 0.126 & 0.093 & 0.117 & 0.094 & 0.106 & 0.105 & 0.158 & 0.147 & 0.177 \\
\hline & -0.750 & 2.81 & 1.93 & 2.80 & 3.16 & 3.19 & 2.01 & 3.93 & 3.94 & 2.27 \\
\hline Agriculture and Fishery & 0.154 & 0.160 & 0.144 & 0.139 & 0.157 & 0.133 & 0.132 & 0.130 & 0.135 & 0.153 \\
\hline & 9.65 & 5.29 & 6.16 & 5.90 & 8.36 & 7.11 & 7.85 & 7.64 & 7.43 & 5.50 \\
\hline Manugfacturing, Construction & 0.158 & 0.212 & 0.217 & 0.221 & 0.251 & 0.203 & 0.166 & 0.117 & 0.090 & 0.087 \\
\hline & 7.57 & 7.02 & 6.97 & 7.49 & 10.42 & 9.74 & 7.29 & 5.30 & 3.55 & 2.47 \\
\hline Constant & 1.468 & 1.244 & 1.346 & 1.412 & 1.422 & 1.470 & 1.517 & 1.573 & 1.624 & 1.734 \\
\hline & 32.01 & 14.55 & 15.32 & 15.40 & 17.73 & 19.07 & 21.79 & 22.86 & 18.53 & 20.43 \\
\hline $\mathrm{R}^{2}$ & 0.395 & 0.162 & 0.171 & 0.198 & 0.223 & 0.246 & 0.283 & 0.304 & 0.343 & 0.372 \\
\hline No. of observations & 2,849 & 2,849 & 2,849 & 2,849 & 2,849 & 2,849 & 2,849 & 2,849 & 2,849 & 2,849 \\
\hline
\end{tabular}

Note to Table 2: i) Source: Spanish National Immigrant Survey; ii) Heteroskedastic-robust t-statistics are in smaller type; iv) additional controls: 19 dummies for Spanish Autonomous Communities; v) Reference individual has less than secondary edcuation, is married, has not been unemployed for more than three months in the past, has a non-permanent contract, resides legally in Madrid, comes from Central-Western Europe and has average experience and years since migration. 
Table 3 - Inter-quantile hypothesis testing by education levels

\begin{tabular}{|c|c|c|}
\hline Test between selected quantiles & Tertiary education & Secondary education \\
\hline $10 q$ equal to $50 \mathrm{q}$ & $\mathrm{F}(1,2823)=0.34(\mathrm{p}$-value $=0.56)$ & $\mathrm{F}(1,2823)=2.25(\mathrm{p}$-value $=0.14)$ \\
\hline $50 \mathrm{q}$ equal to $90 \mathrm{q}$ & $\mathrm{F}(1,2823)=2.15(\mathrm{p}$-value $=0.14)$ & $\mathrm{F}(1,2823)=10.76(\mathrm{p}$-value $=0.00)$ \\
\hline $10 q$ equal to $90 q$ & $\mathrm{~F}(1,2823)=3.53(\mathrm{p}$-value $=0.03)$ & $\mathrm{F}(1,2823)=4.52(\mathrm{p}$-value $=0.00)$ \\
\hline All quantiles equal & $F(2,2823)=4.52(p$-value $=0.00)$ & $F(2,2823)=6.01(p-$ value $=0.00)$ \\
\hline
\end{tabular}

